\title{
Solute Transport Under Water Table Fluctuations in a Fine Sand and a Sandy Clay Loam Soil
}

\author{
Cesáreo Landeros-Sánchez ${ }^{1}$, Itzel Galaviz-Villa ${ }^{2}$, Ma. del Refugio Castañeda-Chávez ${ }^{2}$, Fabiola Lango-Reynoso ${ }^{2}$, \\ Alejandra Soto-Estrada ${ }^{1} \&$ Iourii Nikolskii-Gavrilov ${ }^{3}$ \\ ${ }^{1}$ Colegio de Postgraduados, Campus Veracruz, México \\ ${ }^{2}$ Instituto Tecnológico de Boca del Río. Boca del Río., Ver., México \\ ${ }^{3}$ Colegio de Postgraduados, Campus Montecillo, México \\ Correspondence: Cesáreo Landeros-Sánchez. Colegio de Postgraduados, Campus Veracruz Apartado postal 421. \\ Veracruz, Ver., México. Tel: 1-229-201-0770. E-mail: clandero@colpos.mx
}

Received: September 13, 2013 Accepted: October 16, 2013 Online Published: December 15, 2013

doi:10.5539/jas.v6n1p29 URL: http://dx.doi.org/10.5539/jas.v6n1p29

\begin{abstract}
Drainage contributes to removing the excess of water from cultivated land. In general, most common drainage systems lead to loss of fertilizers applied for plant growth and yield improvement. Thus, the main objective of this work was to study experimentally the redistribution of solutes within the soil profile caused by water table fluctuations by making use of a non-reactive tracer in laboratory studies on soil columns. Two soil materials, namely fine sand and a sandy clay loam soil, were used in this study. Use was made of potassium chloride as a non-reactive tracer. Profiles of chloride redistribution as a function of depth caused by a first drainage of a saturated column with chloride in the surface layer, sub-irrigation and a second drainage were obtained for the fine sand columns with draining water levels at depths 25.5 and $44.5 \mathrm{~cm}$, and for the sandy clay loam columns with a draining water level at depth $44.5 \mathrm{~cm}$. Although only results for water table depth at $44.5 \mathrm{~cm}$ for both soils materials are presented. The redistribution of chloride in both the fine sand and the sandy clay loam columns was dominantly attributed to convective movement of solutes and was considered to be little influenced by diffusion. Preferential flow could have taken place through large sized pores of the fine sand columns. The knowledge and data of this study is a contribution towards that needed to define operation strategies for sub-irrigation-drainage systems which can lead to optimize fertilizers use by crops.
\end{abstract}

Keywords: solute redistribution, drainage, sub-irrigation, soil column experiment

\section{Introduction}

The removal of agricultural chemicals and nutrients from the soil surface by surface runoff and their transport by percolation from the root zone into ground water are of concern from both economical and environmental view points (Hubbard et al., 1989; Hillel, 1998; Paramasivam et al., 2002; Landeros et al., 2012). The loss of nutrients from the root zone requires replacement by the farmer at an additional cost. On the other hand, agricultural chemicals in surface and ground water have become a great concern to the environmental agencies because of their effect on drinking water quality, on ecological systems and on the very lives of human beings (Galaviz et al., 2010; Galaviz et al., 2011; Landeros et al., 2012).

One of the systems in which transfer of solute and water takes place is the so called "subirrigation-drainage" system (Skaggs, 1981; Evans \& Skaggs, 1996; Skaggs \& Chescheir, 2003; Wesström \& Messing, 2007). This system is the combination of a controlled drainage and a sub-irrigation system by open channels or subsurface pipes. Controlled drainage occurs when the system is used to conserve water by reducing drainage outflows and when no additional water is pumped in. During dry periods, water may be pumped into the control outlet where it moves back into the soil through the drainage network, thus raising the water level in the land. In this situation the system is used as a subirrigation system (Evans \& Skaggs, 1996). According to Evans and Skaggs (1996), the advantages of this combined system are, that:

a) It satisfies both drainage and irrigation needs at lower initial costs;

b) It needs less energy, labour and maintenance; 
c) It lowers operational costs due mainly to reduced energy consumption;

d) It conserves rainfall better depending on management strategy;

e) It reduces evaporation during water addition;

f) It provides less obstruction in the field so that operators can continue their cultural practices with no interference;

g) It offers more flexibility in managing drainage water; and

h) It improves the quality of drainage water.

Drainage works used for sub-irrigation-drainage systems have in general evolved in the following way: At first, a free drainage system seemed to be the solution, from the water management view point, for zones where excess water hindered the development of agricultural activities. Through this system low lands started to be converted into arable lands and crop yields were improved in zones with excess water problems. Then, it was realised that a free drainage system was causing a shortage of water which obviously had negative impacts on crop yield and the environment. This situation gave rise to controlled drainage systems; finally, with the addition of some control structures and the redesign or readjustment of drain spacing, the controlled drainage system became a double purpose system.

Controlled drainage and sub-irrigation systems are normally designed with closer drain spacing than conventional drainage systems so as to provide the drainage capacity needed for trafficability and crop protection when the water table is raised. As a result, drainage outflow rates and nutrient transport can be significantly greater than those from conventional systems if the system is not properly managed.

Most of the research work related to controlled drainage and sub-irrigation systems has been focused on design criteria to give guidance on how to manage the water table in order to satisfy crop water requirements together with operation and maintenance aspects (Skaggs, 1981; Evans \& Skaggs, 1996; Crosley, 2004; Alishir et al., 2012). However, concern has been shown by scientists and governments concerning the effect of these systems on the environment (Skaggs \& Gilliam, 1981; Deal et al., 1986; Postel, 2003; Zegbe \& Serna, 2012).

The monitoring of nutrient losses from fields has generally been carried out through measurements on the drainage effluent, both in surface runoff and in subsurface outflow (Kovacic et al., 2000; Alan \& Castillo, 2007; Blann et al., 2009). However, it is also of great importance to crops to know how a specific water table management approach affects nutrient concentration or redistribution in the soil profile so that the management approach can be improved in order to reduce nutrient losses and to maintain nutrients in the root zone.

A fluctuating water table produces, amongst other things, a redistribution of solutes (nutrients) in the soil profile. This seems not to have been closely studied and quantified in solute transport-related studies in subirrigation-drainage systems. Thus, knowledge about solute redistribution in the soil as a result of water-table fluctuations is required in order that criteria for operating sub-irrigation-drainage systems in the field may be better defined in order that both water and nutrients are made available to crops during the growing period.

Therefore, considering the fact that it is not yet fully known how the nutrient status in the root zone is modified or affected by a fluctuating water table, the main objective of this work was to study experimentally the redistribution of solutes within the soil profile caused by water table fluctuations by making use of a non-reactive tracer in laboratory studies on soil columns.

\section{Method}

\subsection{The Laboratory Experiments}

\subsubsection{The Laboratory Columns}

Laboratory columns, $60 \mathrm{~cm}$ in height, of two soil materials fine sand and a sandy clay loam were used in the investigation reported herein. These soils classes were chosen to facilitate the soil column sampling procedure used at the end of each stage studied. The soil materials' main physical characteristics are given in Table 1 . They were packed in PVC cylinders with internal diameter of $9.4 \mathrm{~cm}$ made up of six sections of $10 \mathrm{~cm}$ long each. At the base of the column was deposited a $3 \mathrm{~cm}$ gravel layer where a perforated T-piece was placed for sub-irrigation and drainage. A drainage tap (T1) connected to a flexible rubber tubing, allowed drainage or sub-irrigation of the column to any desired water table depth. The column containing the soil material could be isolated from the water supply system with the tap T2. An observation tube was used to observe the water table position in the static equilibrium state. 
Table 1. Particle size analysis, soil moisture content at saturation $\left(\theta_{\mathrm{s}}\right)$, saturated hydraulic conductivity $(\mathrm{Ks})$, and bulk density at packing $\left(\rho_{\mathrm{b}}\right)$

\begin{tabular}{|c|c|c|c|c|c|c|}
\hline \multirow{2}{*}{ Soil } & Sand & Silt & Clay & \multirow{2}{*}{$\begin{array}{c}\theta_{\mathrm{s}} \\
\text { (\% by vol.) }\end{array}$} & \multirow{2}{*}{$\begin{array}{c}\mathrm{K}_{\mathrm{s}} \\
\text { (m/day) }\end{array}$} & \multirow{2}{*}{$\begin{array}{c}\rho_{\mathrm{b}} \\
(\mathrm{g} / \mathrm{cm} 3)\end{array}$} \\
\hline & & $(\%)$ & & & & \\
\hline Fine Sand & 99 & 0.5 & 0.5 & 38 & 209.0 & 1.7 \\
\hline Sandy clay loam & 66 & 13 & 21 & 51 & 1.5 & 1.3 \\
\hline
\end{tabular}

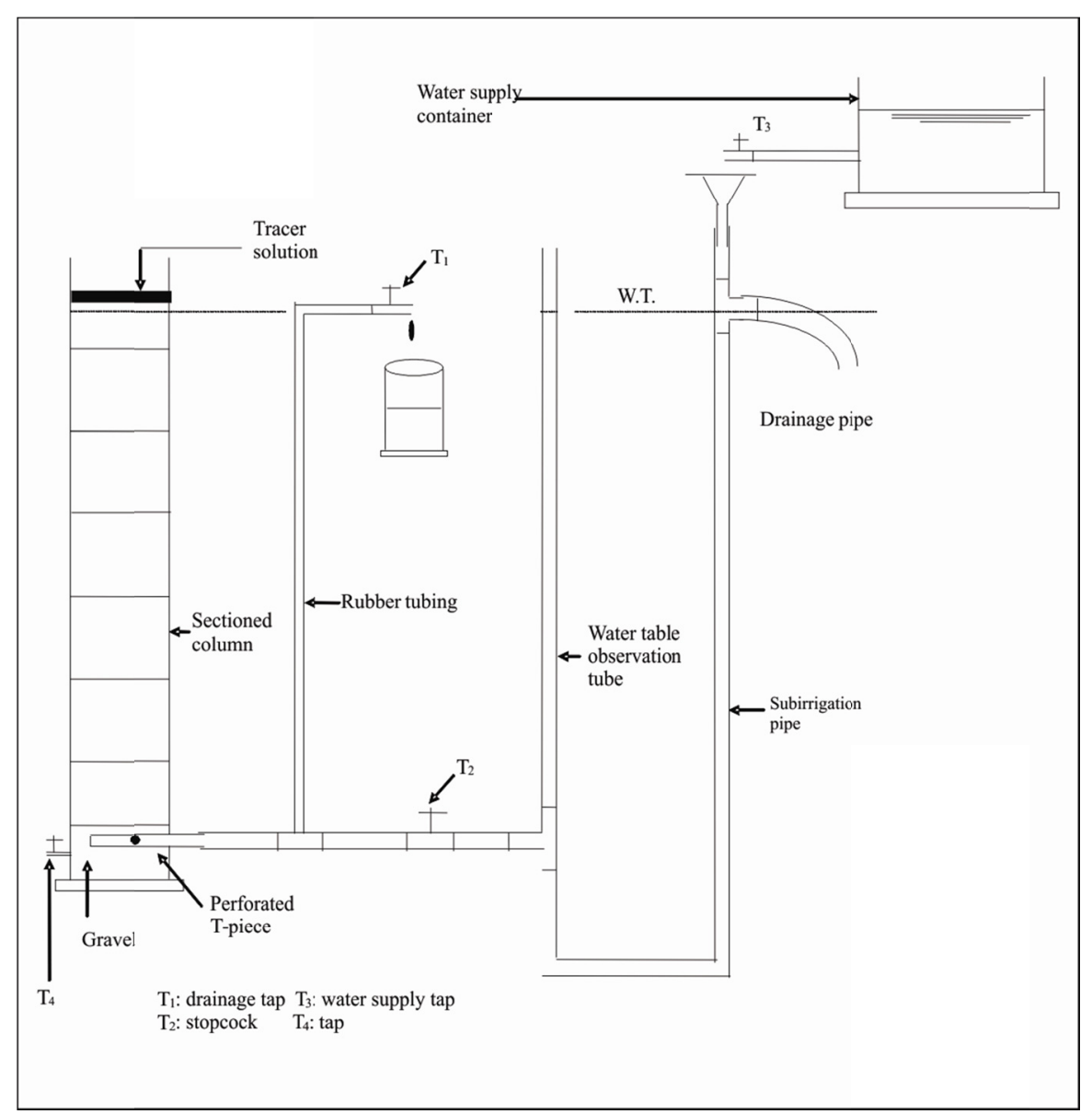

Figure 1. Column installation used in laboratory experimental work

The packing of the column was done section by section by tamping air-dry soil material in layers of approximately $2 \mathrm{~cm}$. Silicon grease was applied on the inner wall surface of the PVC cylinder in order to deter preferential flow between the wall and the soil material. Once a section was packed, another PVC section was fixed on top of it using silicon grease and then tape was wrapped round the joints to keep the column firm. Sections were added and the soil material packed until the whole column was $55 \mathrm{~cm}$ height. The bulk density of the fine sand columns was $1.7 \mathrm{~g} / \mathrm{cm}^{3}$ and that for the sandy clay loam was $1.3 \mathrm{~g} / \mathrm{cm}^{3}$. No soil columns without silicon grease were included in this research work. It must be mentioned that the amount of silicon applied to the wall of PVC columns was very small and therefore it was assumed that this material had no influence on water and solute transport during the whole experimental process of this study (Landeros et al., 2012).

\subsection{Experiments}

The laboratory experiments were designed to trace the movement of a chemical applied on the surface of soil columns caused by a fluctuating water table, simulating the redistribution of surface applied fertilizers. It was initially intended to use potassium bromide and trace its movement with the fluctuating water table. However, as a result of inconsistencies observed in the spectrophotometer of determining the bromide concentration in the samples of soil solutions, potassium chloride was finally chosen as the tracer as this gave consistent results. The 
experiments involved three stages.

\subsubsection{Stage 1}

The soil columns were first saturated by sub-irrigation through the base of the column by supplying distilled water from a supply tank while the water level in the observation tube was maintained at about $1 \mathrm{~cm}$ below the top soil surface of the columns. When no more water was taken up by the column, i.e., when the water table in the column was also about $1 \mathrm{~cm}$ below the top soil surface, the closed drainage tap (T1) was placed at this water level. A volume of $30 \mathrm{ml}$ of the potassium chloride tracer solution with a concentration of $1500 \mathrm{mg} / \mathrm{l}$ was then gently poured on top of the column. The drainage tap (T1) was then turned on so as to allow a displacement of a volume of water from the column approximately equal to that of the tracer solution added. This took about 20 minutes for the fine sand columns. In the case of the sandy clay loam columns the same time was allowed, although the volume of water displaced was smaller than that of the tracer added. The purpose of this operation was to bring the tracer into contact with the soil material in the top $1 \mathrm{~cm}$ of the column in order to resemble the surface application of fertilizers to the soil under field conditions. The top of the columns were covered with plastic to prevent evaporation. After this, the drainage tap (T1) was moved down to a pre-set level and water started to drain out of the column under the influence of gravity. Drainage continued for 24 hours after which drainage had almost ceased and the water table was at the level shown by the observation tube.

Then soil sampling for water content and solute content of the column when the soil was unsaturated was done by detaching each section using a cheese cutting wire and separating the section with a thin metal plate and then extruding the soil using a jack on the base of each section of the column. Slices, usually $2 \mathrm{~cm}$ thick, were cut off in succession. In the saturated soil, soil samples were taken using a spatula as well as extracting soil solution at the end of a simulation with a hypodermic needle entering the side of the column through small holes that were sealed during the simulation runs.

The soil moisture content on a dry weight basis was determined on the whole soil sample by measuring the water lost after oven-drying at $105^{\circ} \mathrm{C}$ for 24 hours for the fine sand and for 48 hours for the sandy clay loam. The volumetric moisture content was then obtained by multiplying the moisture content on a dry weight basis by the dry bulk density of the soil sample (the dry weight of the slice divided by its volume). The chloride concentration was determined on the oven-dried soil samples. The following procedure was followed:

a) Using the whole soil sample, for every $100 \mathrm{~g}$ of soil a volume of 60 to $70 \mathrm{ml}$ of distilled water was added and thoroughly mixed with the spatula;

b) The mixtures were kept in beakers of $600 \mathrm{ml}$ capacity for 14 hours preventing evaporation by covering the beakers with plastic bags;

c) The mixtures were then stirred up again manually for 2 minutes using a spatula. The purpose of this operation was to dilute completely the tracer chloride that was present in the sample;

c.i) in the case of the fine sand the extracts were decanted into different containers and centrifuged at a speed of $4000 \mathrm{rpm}$ for 17 minutes in order to make the extracts clear for analysis; and

c.ii) in the case of the sandy clay loam soil, the mixtures were transferred into a Buchner funnel and filtered using Whatman No. 1 filter paper to obtain the extracts for analysis. The chloride concentration on the extracts (samples) was determined by the spectrophotometric method. Also the water that drained out of the soil columns was collected and measured, and its chloride concentration determined.

\subsubsection{Stage 2}

Using a fresh column, the procedure given in stage 1 was repeated. However, instead of sampling the column after 24 hours, the drainage tap (T1) was turned off and the column rewetted again by sub-irrigation with distilled water. When the water table reached a depth of about $1 \mathrm{~cm}$ below the soil surface, the rewetting of the column was stopped by turning off the taps T2 and T3. The rewetting time was 2.4 hours for the fine sand and 7.2 hours for the sandy clay loam soil. The column sampling device used for unsaturated soil as indicated in stage 1 could not be used because of lack of soil strength of saturated soils. Instead, in the case of the columns packed with fine sand, soil solution samples of 2 to $4 \mathrm{ml}$ were extracted using a hypodermic needle entering the side of the column through small holes located at every $3 \mathrm{~cm}$ which were sealed during the simulation runs. The chloride concentration of the soil solution samples was determined using the spectrophotometric method to give the concentration profile down the soil column. In the case of columns packed with the sandy clay loam soil the hypodermic needle technique of obtaining soil solution samples did not work because the fine soil particles 
blocked the needle. For these soil columns, slices of $2 \mathrm{~cm}$ thickness were taken using a spatula. The soil water and chloride content of soil samples were then determined in the same way as in stage 1 .

\subsubsection{Stage 3}

Columns packed with the fine sand. The columns sampled with a hypodermic needle after stage 2 were for this stage allowed to drain for 24 hours by turning on $\mathrm{T} 1$ positioned at the same level as in stage 1 . After this time T1 was then turned off and the soil column above the water table was sampled in the same way as in stage 1 . For sandy clay loam columns, fresh columns were used repeating stage 1 and stage 2 without sampling. Like in the find sand columns, the drainage tap, being positioned at the pre-set water level, was then turned on for 24 hours. The soil column above the water table was sampled as in stage 1 . The moisture content and chloride concentration down the columns were determined as described in stage 1 .

Thus, stages 2 and 3 in the fine sand columns were carried out on the same column although a different sand column was needed for stage 1 . In the case of the sandy clay loam soil each stage required a different soil column. As mentioned before, for the fine sand columns draining water levels of 25.5 and $44.5 \mathrm{~cm}$ below the soil surface were used in different experiments. For the sandy clay loam soil a draining water level of $44.5 \mathrm{~cm}$ was used. In all cases, two replicates were done.

The chloride concentration in the soil solution existing under the moisture conditions in the columns at the end of stages 1,2 and 3 were calculated from the concentrations obtained from the samples analysed in the spectrophotometer. Sub-samples of fine sand taken at the time the columns were packed had chloride concentrations averaging $1.3 \mathrm{mg} / 1$. Chloride concentrations obtained using the spectrophotometer for the fine sand columns therefore had to be adjusted by subtracting this background chloride concentration from them. In the case of the sandy clay loam soil, a "blank" was run in order to know its background chloride concentration since in this case a higher level of chloride could be displaced during the initial wetting up. This consisted of a column packed with the sandy clay loam soil which was wetted by subirrigation using the laboratory experimental set up depicted in Figure 1. After wetting the column was sampled in the same way as in stage 2 and the chloride concentration in the soil samples determined as mentioned in stage 1 .

\section{Results}

\subsection{Soil Water Profiles}

Only results obtained from columns with a draining water level at $44.5 \mathrm{~cm}$, either find sand or sandy clay loam soil, will be considered in this section. The soil water profiles measured at the end of stages 1,2 and 3 for these two soil materials are presented in Figures 2 and 3 respectively. Soil water content values measured at the end of stage 2 for sandy clay loam soil appeared to be smaller than those measured at the end of stages 1 and 3 for layers adjacent to the water table. This situation may be attributed to: hysteresis effects by which water flow and solute transport can significantly be influenced in variably saturated porous media, entrapped air in the soil pores during the rewetting process and probably to sedimentation of fine particles during the packing of columns.

The equilibrium soil-water profiles at the end of each stage in the soil columns used in the experiments gave the soil moisture characteristics for the fine sand and the sandy clay loam soil. The height above the water table could be assumed in this equilibrium condition to be the soil-water pressure in the soil materials. The volume of drainage water collected from the fine sand columns at the end of stages 1 and 3 were much larger than those of the sandy clay loam columns as shown by different soil water profiles of these soil materials presented in Figures 2 and 3. 


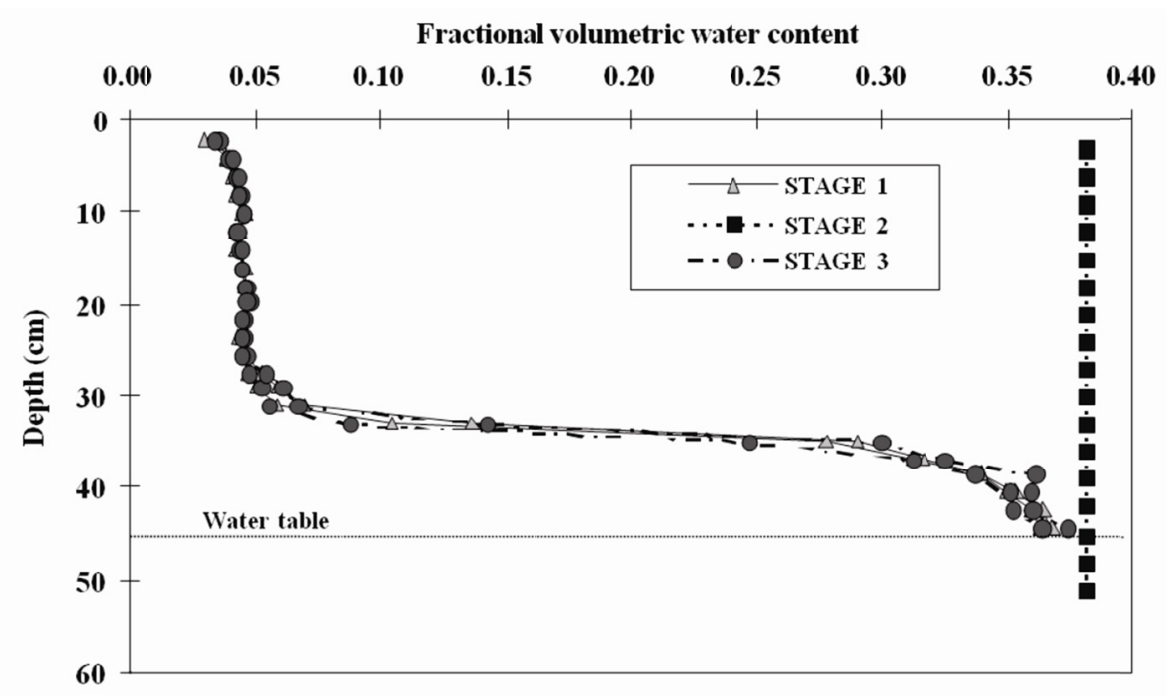

Figure 2. Volumetric water content as a function of depth at the end of stages 1, 2 and 3 for the fine sand

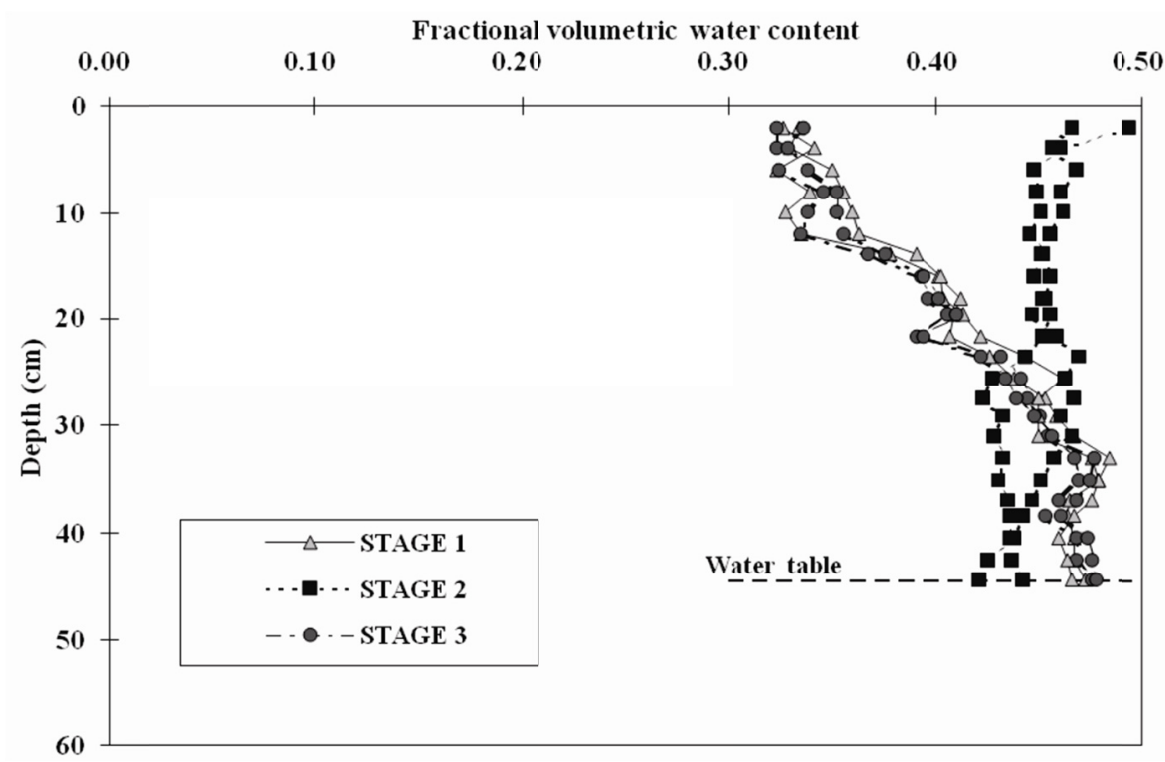

Figure 3. Volumetric water content as a function of the depth at the end of stages 1, 2 and 3 for the sandy loam soil

\subsection{Chloride Redistribution Profiles}

The Figures 4 and 5 show the profiles of mass of chloride per unit volume of soil and draining water level $44.5 \mathrm{~cm}$ below the soil surface at the end of stages 1 and 3, and stage 2, respectively, for the find sand columns. It is observed from Figure 4 that chloride redistributed down to the water table depth during the draining stages. It is seen from Figures 2 and 4 that find sand columns layers whose moisture content was between the zone of residual moisture content and the wet zone appeared with a relatively high amount of chloride and some relatively small quantities of chloride reached the water table with some of it leaching out of the column. It was found that on average $1.2 \%$ of the $45 \mathrm{mg}$ chloride applied to all the fine sand columns was found in the drainage water. Stage 3 graphs presented in Figure 4 show in general masses of chloride per unit volume of soil lower than those observed after stage 1 in the top layers; however, near the water table more chloride per unit volume of soil was found after stage 3 than at the end of stage 1 . After the wetting stage 2 it was observed that most of the chloride was brought back into the top layers as shown in Figure 5. 


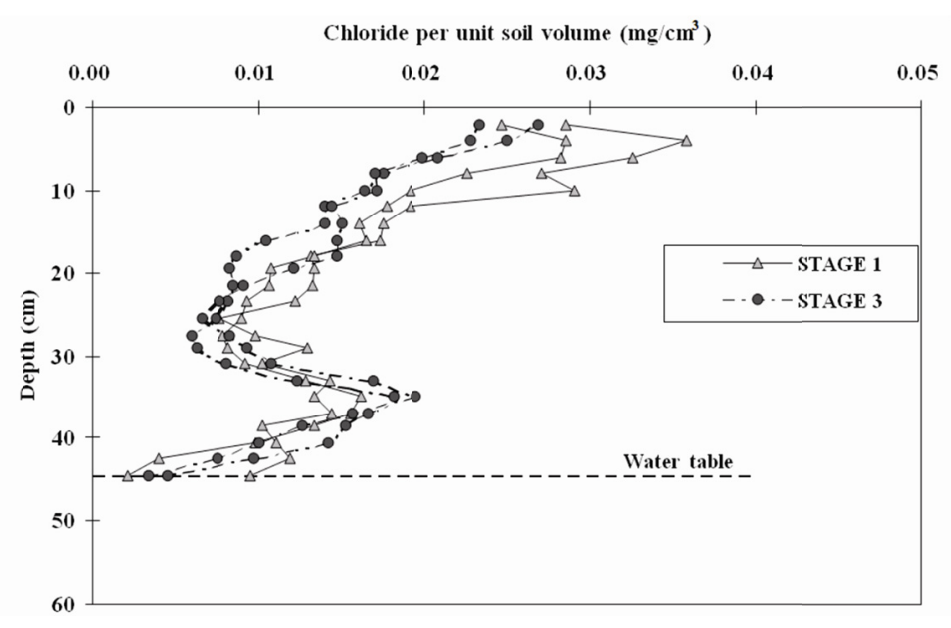

Figure 4. Mass of chloride per unit soil volume as a function of the depth at the end of stages 1 (columns 8 and 6 ) and 3 (column 2 and 1 ) for the fine sand

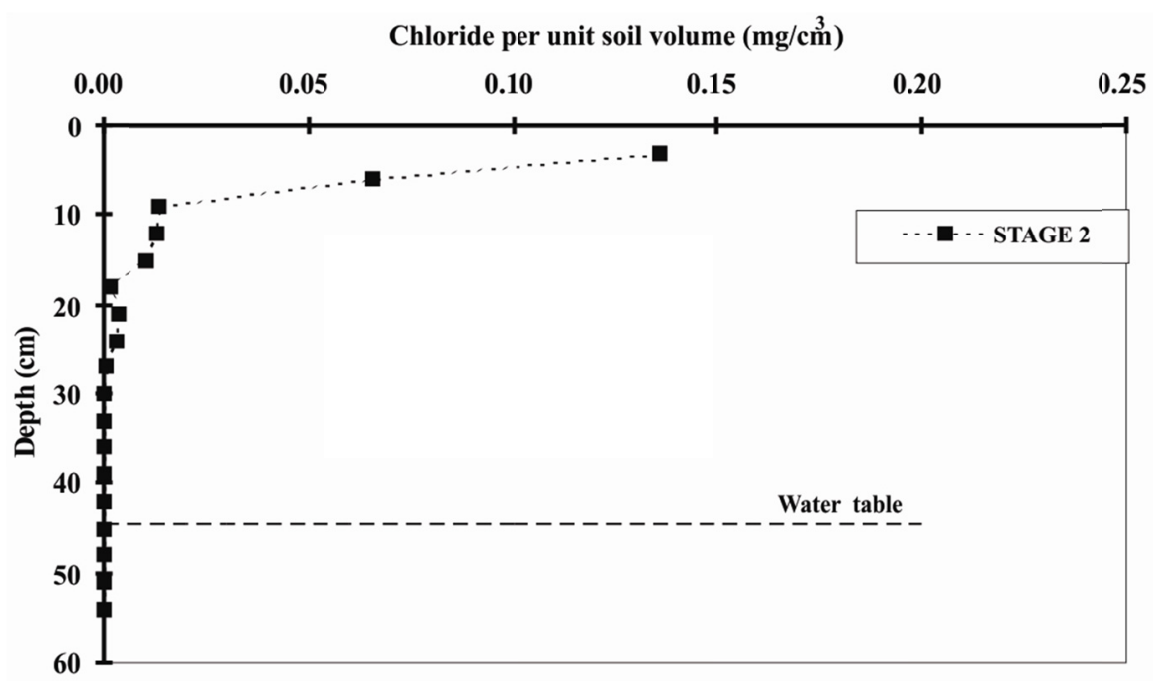

Figure 5. Mean mass of chloride per unit soil volume as a function of the depth at the end of stages 2 for the fine sand

Chloride redistribution profiles for columns packed with the sandy clay loam soil are presented in Figure 6 which shows the profiles expressed as the mass of chloride per unit volume of soil as a function of depth at the end of stages 1,2 and 3. The background chloride of this soil is also presented in this figure which was assumed to be the initial mass of chloride or the concentration of chloride in the soil. In these experiments it was observed that on average $65 \%$ of the $45 \mathrm{mg}$ of chloride applied to the soil columns was found in the top $4 \mathrm{~cm}$-layer at the end of stage 1; the rest of the applied chloride was redistributed down to a depth of $25 \mathrm{~cm}$. At the end of stage 2, $77 \%$ of the $45 \mathrm{mg}$ of the chloride applied was found in the top $4 \mathrm{~cm}$-layer; the rest of it redistributed down to a depth of $21.5 \mathrm{~cm}$ approximately. The distribution of chloride observed at the end of stage 3 was similar to that after stage 1 . The chloride found in the drainage water could originate from the background chloride content of this soil, since the chloride concentration of the graphs presented in Figure 6 was almost equal to that of the background chloride concentration of the "Blank" column. 


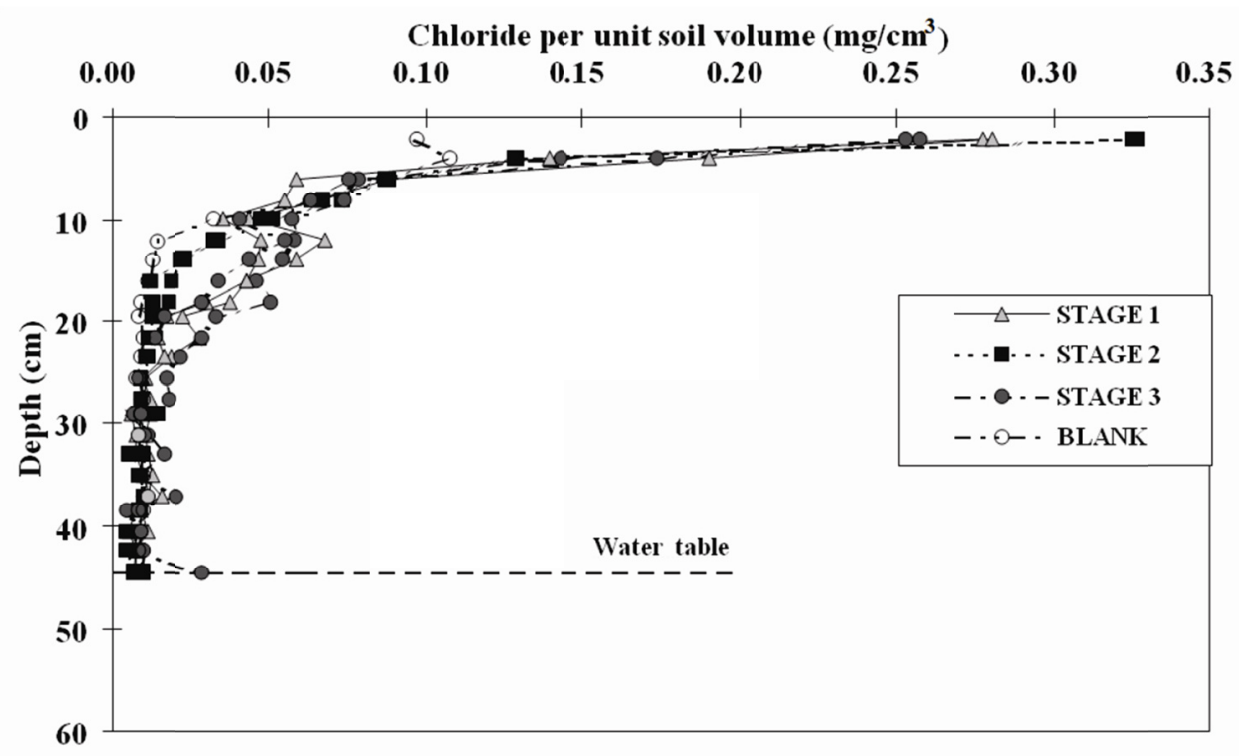

Figure 6. Mean of mass of chloride per unit soil volume as a function of the depth at the end of stages 1,2 and 3, and BLANK for the sandy clay loam soil

\subsection{Solute Balances}

The amounts of chloride recovered in the fine sand and sandy clay loam columns are presented in Table 2 . The "Difference" column shows the difference between the chloride applied and that measured after the experiment. The negative positive values obtained in the "Difference" column give an indication of experimental errors. These included errors pertaining to the column sampling technique, errors during the dilution of extracts when using the spectrophotometer and errors in using the spectrophotometer.

Table 2. Recovery of chloride after stages 1, 2 and 3 for both fine sand and sandy clay loam columns

\begin{tabular}{|c|c|c|c|c|c|c|c|}
\hline Soil & $\begin{array}{l}\text { Water table } \\
\text { depth }(\mathrm{cm})\end{array}$ & $\begin{array}{l}\text { Column } \\
\text { No. }\end{array}$ & Stage & $\begin{array}{l}\text { Initial } \\
\text { chloride } \\
(\mathrm{mg})\end{array}$ & $\begin{array}{l}\text { Chloride } \\
\text { applied (mg) }\end{array}$ & $\begin{array}{l}\text { Chloride } \\
\text { recovered } \\
(\mathrm{mg})\end{array}$ & $\begin{array}{l}\text { Difference } \\
(\mathrm{mg})\end{array}$ \\
\hline \multirow[t]{5}{*}{ Fine sand } & 44.5 & 8 & 1 & - & 45 & 53 & -8 \\
\hline & & 6 & 1 & - & 45 & 45 & 0 \\
\hline & & 2 & 2 & - & 45 & 52 & -7 \\
\hline & & 2 & 3 & - & 45 & 40 & 5 \\
\hline & & 1 & 3 & - & 45 & 42 & 3 \\
\hline \multirow{6}{*}{$\begin{array}{l}\text { Sandy } \\
\text { clay loam }\end{array}$} & 44.5 & 6 & 1 & 77 & 45 & 124 & -2 \\
\hline & & 3 & 1 & 97 & 45 & 142 & 0 \\
\hline & & 2 & 2 & 77 & 45 & 123 & -1 \\
\hline & & 3 & 2 & 77 & 45 & 120 & 2 \\
\hline & & 3 & 3 & 103 & 45 & 148 & 0 \\
\hline & & 6 & 3 & 77 & 45 & 121 & 1 \\
\hline
\end{tabular}

Note: a) the "initial chloride" in columns 3-stage 1 and 3-stage 3 were estimated by doing an input-output mass balance and b) "chloride recovered" values include the amount of chloride lost in the drainage water. 


\section{Discussion}

The difference between the soil moisture profiles obtained at the end of stage 1 and those at the end of stage 3 is due to hysteresis. The volume of drainage water collected from the fine sand columns at the end of stages 1 and 3 were much larger than those of the sandy clay loam columns, as shown by different soil moisture profiles of the fine sand and sandy clay loam soil presented in Figures 2 and 3. The reason being that the infiltration rate for the fine sand is higher than that of a sandy clay loam soil. The implications for agriculture are that drainage problems are not normally found in sandy soils. But when dealing with irrigation one has to keep in mind that the irrigation application rate should not be higher than the infiltration rate of the soil that is being cultivated; otherwise, water and soil nutrients can be lost by leaching or runoff.

The redistribution chloride profiles presented in Figures 4 and 5 showed that chloride movement took place largely with the movement of water. In the finer materials (Figure 6) more water was retained with little water draining so that chloride movement was less. Thus, the redistribution of chloride observed at the end of stages 1, 2 and 3 for both the fine sand and sandy clay loam columns can be dominantly attributed to convective movement of solutes. Transport or redistribution of chloride as a result of diffusion was considered to be little because when looking at the theoretical concentration profile developments as a result of diffusion in static conditions, it appeared that after 24 hours the chloride redistributed down to a depth of $3 \mathrm{~cm}$ in the case of the fine sand and approximately $3.5 \mathrm{~cm}$ in the sandy clay loam soil. The movement of chloride from a uniform layer of salt of a given thickness diffusing in a static column was calculated from the diffusion equation solution described by Ayres and Laskar (2006).

The differences observed between the chloride applied and the chloride recovered (Table 2), as stated before, probably arose from the sampling technique of the column, dilution of extracts and spectrophotometer accuracy. The experimental procedure involved in the sampling of the columns could have resulted in losses of soil material, which in turn implied losses of the chloride applied. Because of relatively high chloride concentrations in the soil solution which reached values beyond the calibration curve range of the measuring instrument, some of the extracts had to be diluted in order for the chloride concentration of the extracts to be read in the spectrophotometer. Consequently, some errors could have occurred during this process. The accuracy of the spectrophotometer was estimated to be $\pm 3 \%$, which also contributed to the experimental error. The presence of some background chloride in the fine sand and in the sandy clay loam soil which was not quantified before starting the experiments could also account for the differences between the input and output masses of chloride shown in Table 2. Due to some difficulties in the soil column sampling procedure, the background chloride was not determined in the experimental soil columns used in stages 1,2 and 3. However, in order to account for such background chloride a "blank" for each type of soil was run in a separate soil column, which consisted of columns packed with fine sand and the sandy clay loam soil which were wetted by sub-irrigation using the laboratory experimental set up depicted in Figure 1. After wetting, the columns were sampled in the same way as in stage 2 and the chloride concentration in the soil samples determined as mentioned in stage 1.

In these PVC columns, some water could have flown through large sized pores or down the sides of the fine sand, although attempts to minimize the latter were made by covering the internal surface of the PVC cylinders with silicon grease. The process whereby the movement of water through a porous medium follows favoured routes (fissures or cracks, worm holes, root holes) bypassing other parts of the medium known as preferential flow (Rice et al., 1991; Workman \& Skaggs, 1991; Bruggeman, 1997; Ryan, 2006) could have also contributed to solutes redistribution to lower depth. It is therefore considered that the concentration of chloride shown in Figure 4, which occurred in the transitional zone of the soil moisture profiles shown in Figure 2, was probably caused by preferential flow. This situation was not considered to happen in the sandy clay loam columns (Beven \& Germann, 2013). In fact, the small sizes of particles led to no or little routes between the PVC and the soil packed in.

\section{Conclusion}

From the first studies published, both in the field (Dyer, 1965a) and in the laboratory (Dyer, 1965b; Thomas \& Swoboda, 1970) have shown that anions such as chloride can move through soil faster than the average velocity of the water molecules present. The greater average velocity of ions is considered to be due to the fact that they are excluded from the immediate vicinity of negatively charged soil particles where the water is relatively immobile and from narrow pores where solution velocities are slow. Consequently, when water movement occurs, the anions can be transported through soil faster and to a greater depth than it would if they were associated with all the soil water (Maraqa, Wallace, \& Voice, 1997; Shipitalo, Dick, \& Edwards, 2000). This phenomenon did not appear to happen in the fine sand columns because only $0.5 \%$ of clay was found in the fine sand used in this experimental work. However, the sandy clay loam soil was $21 \%$ clay which might suggest that anion exclusion could have influenced slightly the redistribution of chloride in sandy clay loam columns shown 
in Figure 6, according to Flury, Leuenberger, Studer, and Flühler (2010), the loamy and the sandy soil show completely different transport patterns.

Sub-irrigation-drainage systems have not been widely adopted because of the lack of established design criteria and the lack of information characterizing the operation of these systems in the field. There exists also the need to know the optimum water table level not just for maximum crop yield, but also for maximum reduction of the loss of fertilizer nutrients and nitrate pollution of water supplies.

During the drainage phase of a sub-irrigation-drainage system, the water table moves down when the water level of the ditch collector is lowered. In this process, the moving water table redistributes, by convection, solutes in the soil profile. Likewise when sub-irrigation takes place, the water table rises and solutes, which were redistributed into lower soil layers, as a result of drainage, are brought back into upper soil layers with the moving water table.

In order to accomplish the placement of fertilizer nutrients in the root zone through a given water table management strategy, it is necessary to know how solutes redistribute in the soil profile with the moving water table. The results of this study showed that after a water table drawdown (i.e., stage 1) most of the chloride applied to the top soil surface of the columns was redistributed within the soil column above the water table. This indicates that a water table drawdown can be used as an alternative to placing nutrients around the roots, in order to make nutrients available to the crop root system. In the experiments reported herein the effect of the water table drawdown on the redistribution of chloride was similar for both the fine sand and the sandy clay loam, although there was a greater movement of chloride in the former.

When sub-irrigation took place, in both the fine sand and sandy clay loam columns, most of the chloride that was redistributed down the soil columns, as a result of the first water table drawdown, was brought back into the top soil layers. This was really interesting because it showed that sub-irrigation can greatly contribute to make not only water available to plants but also those solutes (nutrients) which are leached to deeper layers into the soil profile.

\section{Acknowledgements}

Thanks to Consejo Nacional de Ciencia y Tecnología (CONACYT), the Colegio of Postgraduados, Campus Veracruz ("LP18 Impacto y Mitigación del Cambio Climático"), and to the Instituto Tecnológico de Boca del Rio for financial support. Thanks also to Ing Juan Manuel Hernández Pérez for assistance in the preparation of some figures.

\section{References}

Alishir, A., Saeed, T. H., Abdolmajid, L., \& Moosa, M. P. (2012). Investigation of water table management at lysimetery scale in arid and semi-arid condition of Dezful, Iran. Advances in Environmental Biology, 5(11), 3493-3503.

Allan, J. D., \& Castillo, M. M. (2007). Stream ecology: structure and function of running waters (2nd ed.). Springer Science+ Business Media BV.

Ayres, J. W., \& Laskar P. A. (2006). Evaluation of mathematical models for diffusion from semisolids. Journal Pharmaceutical Sciences, 63(3), 351-356. http://dx.doi.org/10.1002/jps.2600630308

Beven, K., \& Germann, P. (2013). Macropores and water flow in soils revisited. Water Resources Research, 49(6), 3071-3092. http://dx.doi.org/10.1002/wrcr.20156

Blann, K. L., Anderson, J. L., Sands, G. R., \& Vondracek, B. (2009). Effects of agricultural drainage on aquatic ecosystems: a review. Critical Reviews in Environmental Science and Technology, 39(11), 909-1001. http://dx.doi.org/10.1080/10643380801977966

Bruggeman, A. C. (1997). Preferential movement of solutes through soils. Doctoral dissertation, Virginia Polytechnic Institute and State University.

Burgoa, B., Hubbard, R. K., Wauchope, R. D., \& Davis, J. G. (1993). Simultaneous measurement of runoff and leaching losses of bromide and phosphate using tilted beds and simulated rainfall. Communications in Soil Science and Plant Analysis, 24(19-20), 2689-2699. http://dx.doi.org/10.1080/00103629309368988

Crossley, P. L. (2004). Sub-irrigation in wetland agriculture. Agriculture and Human Values, 21(2-3), 191-205. http://dx.doi.org/10.1023/B:AHUM.0000029395.84972.5e 
Deal, S. C., Gilliam, J. W., Skaggs, R. W., \& Konyha, K. D. (1986). Prediction of nitrogen and phosphorus losses as related to agricultural drainage system design. Agriculture, Ecosystems and Environment, 18, 37-51. http://dx.doi.org/10.1016/0167-8809(86)90173-8

Dyer, K. L. (1965a). Interpretation of chloride and nitrate ion distribution patterns in adjacent irrigated and $\begin{array}{lllll}\text { nonirrigated Panoche soils. Soil Science } & \text { Society, 29, }\end{array}$ http://dx.doi.org/10.2136/sssaj1965.03615995002900020018x

Dyer, K. L. (1965b). Unsaturated flow phenomena in Panoche sandy clay loam as indicated by leaching of chloride $\begin{array}{lllll}\text { and nitrate } & \text { ions. Soil } & \text { Science }\end{array}$ http://dx.doi.org/10.2136/sssaj1965.03615995002900020006x

Evans, R. O., \& Skaggs, R. W. (1996). Operating controlled drainage and subirrigation systems. Published by the North Carolina Agricultural Extension Service. Publication number AG-356. North Carolina State University. Retrieved fom http://www.bae.ncsu.edu/programs/extension/evans/ag356.html

Flury, M., Leuenberger, J., Studer, B., \& Flühler, H. (1995). Transport of Anions and Herbicides in a Loamy and a Sandy Field Soil. Water Resources Research, 31(4), 823-835. http://dx.doi.org/10.1029/94WR02852

Galaviz-Villa, I., Landeros-Sanchez, C., Castañeda-Chavez, M. del R., Martínez-Davila, J. P., Perez Vazquez, A., Nikolskii-Gavrilov, I., \& Lango-Reynoso, F. (2010). Agricultural Contamination of Subterranean Water with Nitrates and Nitrites: An Environmental and Public Health Problem. Journal of Agricultural Science, 2(2), 17-30.

Galaviz-Villa, I., Landeros-Sanchez, C., Castañeda-Chavez, M. del R., Lango-Reynoso, F., Martínez-Davila, J. P., Perez Vazquez, A., \& Nikolskii-Gavrilov, I. (2011). Presence of nitrates and nitrites in water for human consumption and their impact on public health in sugarcane-producing areas. Tropical and Subtropical Agroecosystems, 13, 381-388.

Hillel, D. (1998). Environmental soil physics. Academic Press San Diego CA.

Hubbard, R. K., Williams, R. G., \& Erdman, M. D. (1989). Chemical transport from coastal plain soils under simulated rainfall: I. Surface runoff, percolation, nitrate, and phosphate movement. American Society of Agricultural Engineers, 32(4), 1239-1249.

Kovacic, D. A., David, M. B., Gentry, L. E., Starks, K. M., \& Cooke, R. A. (2000). Effectiveness of constructed wetlands in reducing nitrogen and phosphorus export from agricultural tile drainage. Journal of Environmental Quality, 29(4), 1262-1274. http://dx.doi.org/10.2134/jeq2000.00472425002900040033x

Landeros-Sanchez, C., Castañeda-Chavez, M. del R., Lango-Reynoso, F., \& Galaviz-Villa, I. (2012). A convective model CONM that simulates solute redistribution caused by water table fluctuations. Journal of Agricultural Science, 4(12), 116-124. http://dx.doi.org/10.5539/jas.v4n12p116

Maraqa, M. A., Roger, B. W., \& Thomas, C. V. (1997). Effects of degree of water saturation on dispersivity and immobile water in sandy soil columns. Journal of Contaminant Hydrology, 25(3), 199-218. http://dx.doi.org/10.1016/S0169-7722(96)00032-0

Paramasivam, S., Alva, A. K., Fares, A., \& Sajwan, K. S. (2002). Vadose zone processes and chemical transport fate of nitrate and bromide in an unsaturated zone of a sandy soil under citrus production. Journal of Environmental Quality, 31, 671-681. http://dx.doi.org/10.2134/jeq2002.0671

Postel, S. L. (2003). Securing water for people, crops, and ecosystems: New mindset and new priorities. Natural Resources Forum. A United Nations Sustainable Development Journal, 27, 89-98. http://dx.doi.org/10.1111/1477-8947.00044

Rice, R. C, Jaynes, D. B., \& Bowman, R. S. (1991). Preferential flow of solutes and herbicide under irrigated fields. American Society of Agricultural Engineers, 34(3), 914-918.

Ryan, M. (2006). Debate on 'Water movement in a structured soil in south-east of Ireland: preliminary evidence for preferential flow. Irish Geography, 39(1), 78-98. http://dx.doi.org/10.1080/00750770609555868

Shipitalo, M. J., Dick, W. A., \& Edwards, W. M. (2000). Conservation tillage and macropore factors that affect water movement and the fate of chemicals. Soil and tillage research, 53(3), 167-183. http://dx.doi.org/10.1016/S0167-1987(99)00104-X

Skaggs, R. W. (1981). Water movement factors important to the design and operation of subirrigation systems. American Society of Agricultural Engineers, 1553-1561. 
Skaggs, R. W., \& Gilliam, J. W. (1981). Effect of drainage system design and operation on nitrate transport. American Society of Agricultural Engineers, 24(4), 929-934, 940.

Skaggs, R. W., Chescheir, G. M. (2003). Effects of subsurface drain depth on nitrogen losses from drained lands. American Society of Agricultural Engineers, 46(2), 237-244.

Thomas, G. W., \& Swoboda, A. R. (1970) Anion exclusion effects on chloride movement in soils. Soil Science, 110(3), 163-166. http://dx.doi.org/10.1097/00010694-197009000-00003

Wesström, I., \& Messing, I. (2006). Effects of controlled drainage on N and P losses and N dynamics in a loamy sand with spring crops. Agricultural Water Management, 87(3), 229-240. http://dx.doi.org/10.1016/j.agwat.2006.07.005

Workman, S. R., \& Skaggs, R. W. (1991). Evaluation of the water management model PREFLO. Transactions of the American Society of Agricultural Engineers, 34, 2053-2059.

Zegbe, J. A., \& Serna-Pérez, A. (2012), Partial rootzone drying to save water while growing apples in a semi-arid region. Irrigation and Drainage, 61, 251-259. http://dx.doi.org/10.1002/ird.635

\section{Copyrights}

Copyright for this article is retained by the author(s), with first publication rights granted to the journal.

This is an open-access article distributed under the terms and conditions of the Creative Commons Attribution license (http://creativecommons.org/licenses/by/3.0/). 